\title{
East/West Relations: A Case Study of Similar Military Patterns and Outcomes Resulting from US Involvement in Vietnam and Soviet Intervention in Afghanistan
}

\author{
Leroy A. Binns \\ Department of Government, University of the West Indies, Mona, Jamaica \\ Email: labenz@dr.com
}

Received 23 July 2015; accepted 26 October 2015; published 30 October 2015

Copyright (C) 2015 by author and Scientific Research Publishing Inc.

This work is licensed under the Creative Commons Attribution International License (CC BY).

http://creativecommons.org/licenses/by/4.0/

(c) (i) Open Access

\begin{abstract}
Wars have been portrayed by the oligarchy to be the mode by which successful political restructuring is achieved and peace is attained. An illustration such as World War II with its aftermaththe reconstruction of Europe and the resemblance of tranquility during the Cold War era, is commonly cited by advocates as a testament to that perception. Yet it is the predetermination of this commentary to counter such contention by way of an analysis of highly contentious revelations associated with the Vietnam and Afghan wars that unequivocally debunk such interpretation, define superpower limitations with regard to transformation and resolve and re-emphasize the vibrancy of nationalism. The ultimate outcome, the unification of Vietnam and the independence of Afghanistan questions, the role of conflict resolution strategies exercised by dominant nation states in the $20^{\text {th }}$ century and beyond.
\end{abstract}

\section{Keywords}

Vietnam and Afghanistan Wars, US and Soviet Foreign Policy, Political Ideologies and Constraints

\section{Introduction}

The Vietnam and Afghan wars are classic examples of the superpowers' mortality. These confrontations that shared ideological rationale, strategies and conclusions also exposed a test of national will and negated many technological advantages. 


\section{Ideological Rationale}

With a reversal of an initial low priority status, the Republican administration which is outraged by suspicions of communism overlooked the issue of nationalism and violated the Geneva Declaration of 1954 by responding in the affirmative to the French request to rescue Vietnam from Marxism. Upon analysis of victory celebrated by Mao Tse Tung's China and the invasion of South Korea by the North Koreans the Americans decided to extend the theory of containment to the Far East in an attempt to maintain a balance of power. In the words of Secretary of Sate Dean Acheson:

We do not lose sight of the fact that Ho Chi Minh has direct contact, communist connections and we do not wish to see colonial empires supplanted by philosophy and political organization emanating from, and controlled by the Kremlin [1].

Underscoring a theme of consistency such school of thought was consequently echoed by the succeeding US leadership. A senior government official and proponent of US military action Walt Rostow following a "green light” rescue mission to Saigon reported the following as President Kennedy's perspective.

Kennedy said that if we walk away from South East Asia the communist takeover would produce a debate greater than the loss of China to communism. The United States would also be violating a treaty commitment to the area. Such a retreat will result in the rise of the left and the right wing isolationism and the loss of confidence in the United States. Kennedy feared that Khruschev and Mao then would act to exploit the shift in the balance of power. As a result Burma might fall and China would be on the boundary of India, when the United States finally reacted there would be a world crisis and possibly a nuclear disaster.

Of corresponding significance is a Capitol Hill consensus in view of the Gulf of Tonkin cataclysm that sealed America's engagement in the Vietnamese ordeal. In sponsorship of the 1964 right wing Republican presidential nominee Senator Barry Goldwater's famous maxim "Extremism in defense of liberty is no vice and moderation in pursuit of justice is no virtue" and stance on a full scale invasion the Chief Executive sought and received carte blanche from 416 House representatives and 88 senators to discharge the war [2].

Years later with mixed emotions inclusive of the 1968 invasion of Czechoslovakia, popular movements in Cuba, Angola, Ethiopia and South Yemen, the reality of unfriendly neighbors on its borders, a recent ascension of Islamic leadership in Iran and the possibility of its influence on Afghanistan the Soviet Union rejected the UN charter on self determination and equally the question of social identity. Responding to the crisis on the grounds of article 4 of the Soviet/Afghan treaty she exercised the Brezhnev doctrine beyond its original Warsaw Pact context to bolster regional hegemony and prevent defection from the camp [3].

\section{Strategies}

By acknowledging incompetence to adequately secure local military personnel to achieve the required results both Washington and Moscow resorted to direct foreign intervention by utilizing their respective troops in the name of bipolarity. In a “win at all cost” propaganda crusade Washington's conclusion of the South as anarchic ignored the unlawful installation of Ngo Dinh Diem in 1955 and resulted in the transfer of 1,364 soldiers in 1961 to 15,000 by the end of 1963 and with increased involvement a war budget of \$2 billion per month in 1966 . On another Asian front the inauguration of Soviet endorsed Babrak Karmal failed to avoid the desertion of over 45,000 troops from the Afghan army in 1979 and subsequent defections thus leading to a replacement of 642,000 Soviet troops over a ten year period.

As a corrective measure the US at first introduced the unpersuasive 1966 mandatory draft policy and later Vietnamization in her quest for victory. According to President Richard Nixon in his November 3, 1969 televised speech to the nation,

In previous administrations we americanized the war in Vietnam. In this administration we are vietnamizing the search for peace. Under the Vietnamization plan I ordered first a substantial increase in the training and equipment of South Vietnamese forces [4].

Considerable damage inflicted upon the Soviet intruders particularly in Bamiyan Province and a civil strike that ravaged Khost and Urgun also produced an identical reaction - the abandonment of an initiation of scores of Russian troops in lieu of Kabul's adoption of obligatory conscription for males and an overture for public sympathy by President Yuri Andropov.

Our plans for political settlement of the Afghan problem are no secret. We have repeatedly stated them publicly. Leonid Brezhnev spoke about that. Our troops are staying in that country at the request of the lawful Afg- 
han government and they continue staying there at the request of the lawful government headed by Babrak Karmal. We responded to the request for assistance from a friendly neighboring country. It is however far from being a matter of indifference to us what is happening directly on our southern border [5].

Confronted with a sense of urgency amidst moments of unbearable embarrassment in the form of the Pleiku American air base incident of 1965 and the guerilla attack in Jallalabad in 1979 both world powers adopted a "by any means necessary" approach to fulfill their objectives. True to form and in accordance with President Lyndon Johnson who once said he would not be "the president" who saw "South East Asia go the way China went" a search and destroy policy was implemented to dismantle and extinguish all remnants of the enemy. Such exercise included Operation Junction City which over the duration of four months from February to May 1967 was responsible for the destruction of supply lines and the annihilation of 2,700 opponents. Further Soviet behavior was akin to that of her Western counterpart through demonstrations by its armed forces around the Western city of Heart and the neighboring villages of Chesht and Band-Salma [6].

A scorch the earth policy was yet another desperate attempt to alter the nature of these debacles. Published accounts reference Strategic Helmet and its aftermath - the systematic destruction of rural economies and subsistence status of country dwellers along with paralleled consequences associated with the Logar resistance. Consequently the aforementioned as well as random shooting of civilians and bombing of towns such as Hue following the 1968 Tet Offensive and Bagram influenced by rebel attacks and relocation transformed Vietnamese and Afghan country-sides and the peripheries of Cambodia, Laos, Pakistan and Iran. In 1981 an ongoing Afghan/Soviet partnership resulted in 170,000 refugees in Pakistan and 400,000 in Iran with numbers skyrocketing in 1984 to 3,500,000 and 1,500,000 in both locations at a cost of over \$500 million to the United Nations [7].

The defining moments of the superpowers' vulnerability also encompassed international dimensions that were largely accountable for the magnitude of the quagmires. On the subject of Vietnam, Cambodia and Laos were instrumental as supply lines for the Viet Cong and therefore faced retaliation. A 1968 North Vietnamese offensive that tallied numerous casualties was a response to an expansive Indochina battle and the release of 2.5 million tons of bombs between 1969 and 1971. In comparable fashion the Soviets were subjected to the usage of China and Pakistan as supply routes for weapons thus prompting an illegal entry and principal military sweeps in Paktia and the Kunar Valley [8].

An extension of foreign intrusion translates beyond the transportation of military hardware. In relation to Saigon, Soviet and Chinese monetary assistance escalated US intransigence. The same holds true in response to a general White House award ranging from $\$ 30$ to $\$ 50$ million per annum for the sustenance of guerilla warfare in Afghanistan and particularly \$250 million and \$710 million earmarked by the same source in 1985 and 1988 respectively for said purpose, plus additional fiscal aid by Egypt and Saudi Arabia and American sponsored training camps facilitated by the Pakistanis. In the words of Soviet Premier Andropov

We consider that as soon as outside interference in the affairs of Afghanistan has been terminated and non resumption of such interference guaranteed we shall withdraw troops [9].

Amid controversial and unpredictable circumstances enticements were utilized to appease the disadvantaged populations. Seeking redemption subsequent to one of the nation's closest presidential elections, President Nixon during his second term offered economic assistance through the lend lease program to revitalize peasant communities of lost properties and displacements and later re-emphasized his commitment through the Vietnamization agenda as did the Kremlin with land reforms that promised an opportunity to access farm land at the expense of land owners. Nonetheless a combination of chaos, distrust and a lack of cohesion necessary for a desired result stymied the realization of an economic revival [10].

A misinterpretation of the tangled web of ethnicity and religious sectors within Vietnam namely the Buddhists, Catholics, Chinese, Chams, Kmers, and Montagnards and Afghanistan (e.g., Sholeh Javid, Settem-E-Melli, Parcham and Khailqi) forged suicidal agendas. Both civil strives displayed a sense of community that overshadowed technological prowess and ignited miscalculations on the part of foreign foes. As time progressed the locals' fortitudes and resolve to withstand the atrocities of warfare magnified their status as the superpowers' rampage of destruction and unwavering objection to international mediation alienated elements of society deemed necessary for their success [11].

Aside from neighborly assistance familiarity with the terrain and the opposition's flawed tactics and despondence the Viet Cong and Mujahadeen gained confidence through support of local villagers and intelligence and armory from defectors. Furthermore public outrage within the United States and the Soviet Union to demonstra- 
tions of deception, inhumanity and pending defeat vilified the overseas combatants in favor of the Asian warriors.

In the end increasing signs of gloom spelt the cessation of the protracted encounters that terminated over 70,000 American and Soviet lives, wounded an extra 500,000 and cost in excess of \$200 billion collectively. Washington began a rapid extraction of soldiers in 1971 and invoked the War Powers Act in 1972 curtailing presidential war capabilities while Moscow agreed to a 1988 diplomatic accord that advocated the withdrawal of Soviet troops from Afghanistan - a pledge that was later realized on February 15, 1989.

An empirical analysis of world power politics at play as defined by the occurrences in question highlights intolerance towards foreign interference and sets in motion an opportunity for reassessment and mediation mutually beneficial to all relevant parties [12].

\section{Conclusion}

Introduction

The Vietnam and Afghan wars have been labeled the superpowers' worst ordeals due to the eroding impact on their reputation.

Vietnam

American foreign policy towards Vietnam was designed to terminate a supposedly spreading monolithic communist movement on route to world domination. In other words Vietnam's national struggle was interpreted as Marxist and addressed accordingly.

There was a noted hypothesis that US national interest would have benefited from an acceleration of imperialism - strong political and economic affiliation with the Orient. Thus in order to achieve these objectives the White House promised the French and later the Vietnamese an economic renewal.

Lost in the illusion of capitalism in Indochina and unfulfilled expectations by SEATO, US engagement began with her refusal to sign the 1954 Geneva Accords that emphatically acknowledged the early prospect of a unified Vietnam under the Viet Minh. Moreover the violation of the UN charter in support of sovereignty and the undemocratic installation of the Diem and Thieu regimes incited a civilian encounter against America—-the lone international participant in a bitterly contested saga.

Subsequently events such as Strategic Helmet and Vietnamization outlined the fact that Capitol Hill misunderstood Vietnamese history. Fearing additional defeats in the Pacific, she proceeded to ignore a people seeking national liberation and the directives from Paris championing accordance with the Geneva commitment. Presidents Eisenhower, Kennedy, Johnson and Nixon were unwilling to forego the stalemate.

The call for victory was unanimous but strategies from the executive branch to the military outfit differed significantly. An occasion depicts President Johnson requesting presidential powers from Congress in place of a declaration of war, a decision highly opposed by the army's rank and file whereas a call by General Westmoreland in 1968 for additional troops was flatly rejected by the then unpopular president. The victory cry was also fragmented by the US government's inaptitude to energize the Vietnamese army and her unwillingness to engage the enemy in a full scale confrontation.

Could the United States of America win the Vietnam War? The popular response within the military and political circles is favorable. However, the retention of a large scale insurgency as an attempt at rectification could have faced an Asian reply of epic proportions and heightened condemnation at home and abroad.

In short a possible alternative was the adoption of moral support for the freely elected government of Vietnam with the intention of fostering socio-economic stability in Saigon and Hanoi. This act of humanity could ultimately secure an indispensable US/Vietnamese relationship.

Afghanistan

In the eyes of the Russian leadership the commonwealth was lacking a covenant for law and order abetting prosperity instead of depredation. Hence ignoring the religious tenets of the society that favor sovereignty the invaders unlawfully became the vortex in a civil strife.

It has officially been stated by the perpetrators that regardless of vilification such conduct was of paramount importance to keep the Afghan subjects united and loyal. Yet the means which were anomalous with the end failed to achieve democracy under the pretext of the propitious Sovietization of Afghanistan.

During the mayhem the Moscovite nexus boosted political institutions in Kabul. With prospects of the exploitation of the country's minerals deposits (e.g., limestone, chrome, iron ore and uranium) and the integration 
of Afghan Turkestan with Soviet Central Asia, the Peoples Democratic Party of Afghanistan and its affiliates, the central committee, the politburo and regional organizations were trained and heavily funded by the Kremlin.

The Russians in spite of obstacles associated with the formation of a new education curricula and the isolation of traditional and Islamic culture had other ideas. To abate American and Chinese presence in the Euroasia theater, they sought to surreptitiously use Afghanistan for outward economic advantages.

A drive for the advancement of Soviet imperialism into East Asia could be fostered by utilization of the Southern tier. This conduit could enhance the transportation of technology while acting as a buffer for the new West/East lifeline connecting Russia with the Pacific via Siberia and the Baikal Amur passage.

Waterways were also sinews of political and economic strength. The Indian Ocean through the Indo-Persian corridor could add access to Iraq, Turkey and possibly Syria while Soviet control of Afghanistan could result in advancements in Pakistan. Further with massive oil reserves at her disposal Soviet overtures to Iran could cripple Western influence in the Middle East.

The negatives are nonetheless glaring, Egypt's, Iran's and Pakistan's refusal to become the torch bearers of Soviet dogma rid Moscow of significant players in the battle for expansionism. The maritime power could also encounter the following economic hardships: all Soviet bases are located in shallow coastal waters and are subject to mining and the Trans-Siberian railway is prone to possible interruption-both of which would entail astronomical cost for protection. Nonetheless the dismantling of the Union Soviet Socialist Republics and her integration into a single world market could aid in the creation of a platform for political and economic cooperation with the Republic of Afghanistan.

Conclusion

In time history will judge if lessons learnt courtesy of the underdogs—Vietnam and Afghanistan have set a precedent for future conflicts.

\section{References}

[1] Turley, W. (1986) The Second Indochina War: A Short Political and Military History 1954-1975. Westview Press, Boulder

[2] Yoder, A. (1986) The Conduct of an American Foreign Policy Since World War II. Pergamon Press, New York.

[3] Philips, J. (1979) Afghanistan: The Soviet Quagmire. The Heritage Foundation Backgrounder, No. 101, Washington DC.

[4] Kimball, W. (1980) American Diplomacy in the 20th Century. Forum Press, Missouri.

[5] Bradsher, H. (1985) Afghanistan and the Soviet Union. Duke University Press, Durham.

[6] Mangus, R. (1985) Afghan Alternatives. Transaction Books, New Jersey.

[7] Giradet, E. (1985) Afghanistan: The Soviet War. St Martin’s Press, New York.

[8] Collins, J. (1986) The Soviet Invasion of Afghanistan. Lexington Press, Toronto.

[9] Urban, M. (1990) War in Afghanistan. St Martin’s Press, New York.

[10] Hammond, T. (1984) Red Flag over Afghanistan: The Communist, the Soviet Invasion and the Consequences. Westview Press, Boulder.

[11] Arnold, A. (1981) Afghanistan: The Soviet Invasion in Perspective. Hoover Institute Press, Stanford.

[12] Grau, L. (2002) The Soviet Afghan War: How a Superpower Fought and Lost. University Press of Kansas, Kansas. 